\title{
The Impact Of Internet Marketing On Profitability
}

Hwei Cheng Wang (E-mail: w2416@yahoo.com), Nova Southeastern University Ninghsin Chen (E-mail: pnhc@mail.cju.edu.tw), Chang Jung Christian University, Taiwan

Hsain-Jane Chang (E-mail: changj@tpe.boehringeringelheim.com), National Taipei University, Taiwan

\begin{abstract}
With the internet user increased, the internet marketing becomes a hot and new marketing channel to sell and buy through internet meanwhile changes buyer behavior. This study examine whether internet marketing become a popular marketing channel or a key marketing channel for the company in future. This paper reports the results of an empirical study of the marketing channel choices (internet and catalog) have different marketing costs to cause different performances on firm profitability. Data on financial statements from internet and catalog retail of COMPUSTAT database that were in existence in 2002 were examined and statistically analyzed the profitability. Comparisons are made, through a series of T-tests, to determine the profitability of their different retail marketing channel choices. The results indicated statistically significant differences in ROE, ROA, and ROS between internet and catalog retail, therefore, the adoption and implementation of different retail marketing channel choices such as internet and catalog did have a different profitability. The results concluded that internet retail or on-line retail may be an additional marketing channel for the company but it can not be a key retail marketing channel due to the negative means of $t$-test results on internet profitability.
\end{abstract}

\section{Introduction}

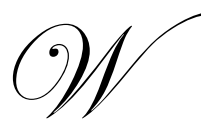

ith the internet user increased, the internet marketing becomes a hot and new marketing channel to sell and buy through internet meanwhile changes buyer behavior. This study examine whether internet marketing become a popular marketing channel or a key marketing channel for the company in future. The channel theory states that selling is the most important of the marketing functions, as well as the most costly one to perform (Weld, 1916; Alderson, 1954; Bucklin, 1966; Stern, El-Ansary, and Coughlan, 1996). The selection of an appropriate marketing channel system becomes of importance for the presence of dependence in the marketing channel (Magee, 1960; Steudel and Desruelle, 1992). Does different marketing channel have different cost to result in different profit? Do the managers select different marketing channel which may have a significant difference in profitability? Could internet retail become the popular and new retail method instead of traditional retailing marketing channel? To explore these issues, this study uses the gross profit margin, net profit margin, return on equity, return on asset and return on sale as the financial indicator of profitability to examine the internet and catalog retail. The basic premise investigated is that a successful choice and implementation channel should result in more profitable in managing a company's marketing channel. These results should be observable in the financial statements of the company. Specifically, the balance sheet and income statement should reflect the different gains obtained with different channel choice.

\section{Literature Review}

The perspective in this article is supported by the channel theory (Weld, 1916; Alderson, 1954; Bucklin, 1966; Stem et al., 1996). Traditionally, channel theory has concentrated on vertical dependencies between firms in the marketing channel. At the same time, a marketing channel consists of a number of actors or intermediaries that take part in the exchange processes, since they may improve the efficiency of the channel (Alderson, 1954). In a marketing channel, activities are specialized, and there is a functional distribution between firms (Bucklin, 1966; 
Alderson, 1954). Stem et al. (1996) state that the job of a channel manager is not done when that optimal channel is designed; the manager now has to make that channel work! There is no guarantee that the optimally designed channel will actually operate successfully. The selection of an appropriate marketing channel system becomes of vital importance for the presence or absence of dependence in the marketing channel (Magee, 1960; Steudel and Desruelle, 1992).

\subsection{Compare And Contrast With Internet And Catalog Retail}

As a marketing channel, internet has both unique characteristics and characteristics that are shared with catalog marketing channel (Peterson, Balasubramanian, and Bronnenberg, 1997). These characteristics include the following: Internet has the ability to inexpensively store vast amounts of information at different virtual locations and the availability of powerful and inexpensive means of searching, organizing, and disseminating such information. Internet could instantly change and provide information real time and on-line. With the ability to provide perceptual experiences, internet retail is far superior to the catalog retail. Internet has relatively low entry and establishment costs for sellers.

\subsection{Channel Intermediaries}

Marketing activity occurs through three types of channels: distribution channels, transaction channels, and communication channels, each of which has a discrete function (Peterson et al., 1997). The function of distribution channels is to facilitate the physical exchange of products and services. Transaction channels generate sales activities between buyers and sellers such as brokers, wholesalers, and retailers. Finally, communication channels enable the exchange of information between buyers and sellers. Although conceptually distinct, in the context of consumer marketing these channels frequently overlap, and channel members may be responsible for multiple functions (Peterson et al., 1997).

The distribution function is frequently incorporates functions such as sorting, inventory holding, allocation, breaking bulk, and building up assortments (Alderson 1965, Peterson et al., 1997). The existence of intermediaries in the distribution channel is supported primarily by the rationale of efficiency (Stern, El-Ansary, and Coughlan 1996).

The function of transaction channels is to facilitate economic exchanges between buyers and sellers. Although transaction channel intermediaries exist because of the efficiencies they provide, they differ from distribution channel intermediaries in that they assume some strategic control over marketing variables such as price and merchandising (Peterson et al., 1997).

The primary function of communication channels is to inform buyers and prospective buyers about the availability and features of a seller's product or service offering (Peterson et al., 1997).

The existence of the internet will affect the transaction channel intermediaries because it will be possible for sellers (producers or manufacturers in particular) to efficiently and directly interact with individual buyers and potential buyers without distance and time constraints.

To examine the marketing channel choices impact on profitability, there are some financial ratios to measure the profitability. Brown, Gatian, and Hicks (1995) state that Return on investment (ROI), return on equity (ROE), and return on assets (ROA) are all closely related and widely accepted profitability measures used by internal management and external analysts to evaluate performance. ROA is used in this study because it measures a firm's ability to generate profits from assets without regard to how those assets are financed. A second measure of profitability, return on sale (ROS) that is consistent with a price down/cost down philosophy held by many Japanese companies, is also used in this study. ROS was argued that it is subject to less manipulation than is ROA. For example, division managers could achieve a higher year-end ROA by postponing an important capital investment. 
Sung, Chang and Lee (1999) uses interpretive approach to bankruptcy prediction and the final input variables were forty financial ratios categorized as growth, profitability, safety/leverage, activity/efficiency, and productivity.

Kane (1997) tests profitability by operating profit to sales, pre-tax income to sales, gross and net profit margin. Therefore, this study adopts gross and net profit margins to examine profitability. Brown, et al. indicate that return on investment (ROI), return on equity (ROE), and return on assets (ROA) are all closely related and widely accepted profitability measures used by internal management and external analysts to evaluate performance. ROA is used in this study because it measures a firm's ability to generate profits from assets without considering to how those assets are financed. In this sense it is a more comprehensive measure; therefore, it is more appropriate than ROI for evaluating marketing channel choices. Return on sales (ROS) that is consistent with a price down/cost down philosophy held by many Japanese companies, is also used in this study. Some would argue that ROS is subject to less manipulation than ROA. For example, division managers could achieve a higher year-end ROA by postponing an important capital investment. However, this type of behavior seems less likely in firms when management philosophy is to invest in innovative technology such as internet retail. Walker and Petty (1978) examine the differences in large and small firms in a sample of firms drawn from the COMPUSTAT database. Variables examined include liquidity, profitability, leverage, risk, and dividend policy. Their results indicated that larger firms have greater liquidity and lower profitability than smaller firms. Therefore, there are some key financial ratios examined in this study. Profitability ratios examined include gross profit margin, net profit margin, return on assets (ROA), return on equity (ROE), and return on sales (ROS).

\subsection{Research Question}

Is there a statistically significant difference in profitability (as expressed by the following accounting measures of profitability: Gross profit margin, Net profit margin, ROE-Return on Equity, ROA-Return on Assets, ROS-Return on Sales) between those retailing marketing channel that were internets and those that were catalogs?

\subsection{Research Hypothesis}

The hypothesis was tested using t-tests significance on the sample means. Throughout this analysis it will be possible to determine if the different marketing channel choice had a impact on profitability.

Null H1: There will not be a significant difference, at a 0.05 level of significance, in profitability between those marketing channel that were internets and those that were catalogs.

H1: There will be a significant difference, at a 0.05 level of significance, in profitability between those retailing marketing channel that were internets and those that were catalogs.

\section{Research Methodology}

The first step in this study was to identify a group of retailing companies that had adopted and implemented internet retail and a group that had adopted and implemented catalog retail through the GICS code of COMPUSTAT database.

\subsection{Research Design}

A set of comparisons was made between internet and catalog retail. The profitability of both internet and catalog retail companies was examined. The following accounting based measures serve as dependent variables for purposes of this study and were used as the profitability comparison points: gross profit margin, net profit margin, ROE-Return on Equity, ROA-Return on Assets, and ROS-Return on Sales. 


\subsection{Sample}

The data for this study was collected from GICS code of COMPUSTAT database to find internet retail and catalog retail of companies. Twelve months of financial data (Jan 1, 2002 to Dec. 31, 2002) were randomly collected for 33 companies of internet retail and 23 companies of catalog retail. Annual reports from internet retail and catalog retail were collected form Standard and Poor's Compustat. The annual reports of the wholesale-drugs and retail-drug stores were analyzed.

\subsection{Data Analysis}

To measure profitability, data on financial statement from internet and catalog retail of GSIC code of COMPUSTAT database that were in existence in 2002 were examined and statistically analyzed their profitability. The profitability ratios examined included the gross profit margin (GPM), net profit margin (NPM), return on equity (ROE), return on asset (ROA), return on sales (ROS). Table 1 shows the ratios and their methods of calculation.

The statistical package for the social sciences version 11 for Windows (SPSS) is used for the data analyses. The data were coded into Microsoft Excel and the sample checked against original returns for encoding errors. The mean ratios for the internet and catalog retail are shown in table 2 .

The investigation is undertaken using a $\mathrm{T}$ test for means. This involves three steps. First, it is necessary to determine whether the variances of samples are the same. The Levene test indicates whether an equal or unequal variance should be assumed. Where the Levene statistic is greater than 0.05 the equal variance $\mathrm{T}$ statistic is used. Where the Levene statistic is less than 0.05 the not equal variance T test is used. Second, the two-tailed T test is calculated using the equal and unequal variance formula. Where the significance of a 2-tailed $\mathrm{T}$ test, using the appropriate variance equality formula, is less than 0.05 the null hypothesis is not accepted. Third, the confidence interval for those ratios shown as significant with the two-tailed test is considered. Where the $95 \%$ confidence interval contains a zero value the null hypothesis cannot be accepted. A summary of the analysis is presented in Table 3.

The financial results for the internet and catalog retail were collected from GICS of COMPUSTAT in 2002. The mean of each sub group was then calculated on the variables of gross profit margin ratio, net profit margin ratio, ROE ratio, ROA ratio, and ROS ratio.

Then, a T-test of significance with a confidence level of $95 \%$ was performed on all variables in order to test the null hypothesis.

\section{Results And Findings}

As stated in the null format, hypothesis posits that there will not be a significant difference, at a 0.05 level of significance, in profitability between those marketing channel that were internets and those that were catalogs. Results of the t-test conducted on the means differences between the internet and catalog are significantly different for each of the 5 ratios examined. The results indicated that catalog has higher profitability ratios than internet retail.

Results of the t-tests conducted on the variables revealed that differences in the mean averages of ROE, ROA, and ROS variables were statistically significant at the .05 level $(\mathrm{t}=-2.481, \mathrm{t}=-2.160, \mathrm{t}=-2.816$, respectively) difference for those retailing that were internet retails and those were catalog retail. The results reject the null hypothesis and concluded that there was a significant difference, at a 0.05 level of significance, in profitability between those retailing marketing channel that those were internets and those that were catalogs retail.

The results found that the mean profitability ratios are negative in internet group except gross profit margin. This results show that internet retail is less profitability than catalog retail due to less return on ROE, ROA and ROS. Due to the negative means of t-test results on internet profitability, it can be concluded that internet retail or on-line retail may be an additional marketing channel for the company but it can not be a key retail marketing channel. 


\section{Summary And Conclusions}

The results of this study indicated that there are significant differences between internet and catalog retail marketing channel. The findings suggested that managers, investors, and decision-makers should be sure to choose an appropriate marketing channel to ensure profit for comparison purposes when examining these ratios.

The results also indicated that there are some rations that are not different across the internet and catalog retail. These ratios are the gross profit margin, and net profit margin. As long as manager is correctly controlled for, these ratios can be expected to exhibit constant proportionality across different marketing channel.

A number of limitations in this study must be noted. First, the sample size was relatively small and not cross-sectional in nature, since the sample was restricted to manufacturing industries. Thus, the generalization of the research results is somewhat limited. The second limitation is that only financial ratio variables were included. There may be other important key quantitative variables such as market value, stock return, size and qualitative variables such as leadership, type of ownership which organization theory reports the importance of these variables. The third limitation is that cost analysis was not applied. The forth limitation is that the possibility of bias in reported industry average profitability ratios due to the nature of the raw data collection process. Finally, this study examined only the differences in the means of rations. A better understanding of the distributional characteristics of rations in internet and catalog retail is also needed. It is important to measure actual monetary implications of misclassification rather than just accuracy.

\section{Suggestions For Future Research}

The study explore whether or not the internet marketing channel profitable to be an key marketing channel and compare the internet marketing channel with catalog channel, so the future research may explore the internet marketing channel with other retailing marketing channel such as distributors, department stores, general merchandise stores, apparel retail, computer \& electronics retail, home improvement retail, etc. to find out whether or not the internet marketing channel may be the key marketing channel in future channel research.

\section{References}

1. Alderson, W., "Factors governing the development of marketing channels." in Clewett, R.M.(Ed.). Marketing Channels for Manufactured Products. Richard D. Irwin, Inc., Homewood, IL, 5-34, (1954)

2. Alderson, W., "Dynamic Marketing Behavior: A Functionalist Theory of Marketing," Richard D. Irwin, Homewood, IL, (1965).

3. Brown, R. M., Gatian, A. W. \& Hicks, J.O. "Strategic information systems and financial performance." Journal of Management Information Systems, Vol.11, No 4, pp.215-249, 1995.

4. Bucklin, L.P., "A Theory of Distribution Channel Structure, University of California, Berkeley," CA, 1966.

5. Kane, G. D., "The impact of recession on the value-relevance of accounting ratios," The Mid-Atlantic Journal of Business, Vol. 33, No. 3, pp. 203-19, 1997.

6. $\quad$ Magee, J.F., "The logistics of distribution.” Harvard Business Review, Vol. 38, No. 4, pp. 89-101, 1960.

7. Peterson, R. A. Balasubramanian,S., \& Bronnenberg, B. J., "Exploring the implications of the internet for consumer marketing." Academy of Marketing Science, Vol. 25, No. 4, pp.329-347, 1997.

8. Stern, L.W., El-Ansary, A.I. \& Coughlan, A.T., Marketing Channels. Prentice-Hall International, Upper Saddle River, NJ., 1996.

9. Stern, L.W., El-Ansary, A. I., \& Coughlan. Marketing Channels, $5^{\text {th }}$ ed. Upper Saddle River, NJ: Prentice \& Hall, 1996.

10. Steudel, H.J. \& Desruelle, P.E.P., "Manufacturing in the Nineties: How to Become a Mean, Lean, World-class Competitor" Van Nostrand Reinhold, New York, NY, 1992.

11. Sung, T. K., Chang, N \& Lee, G., "Dynamics of modeling in data mining: Interpretive approach to bankruptcy prediction," Journal of Management Information Systems, Vol.16, No. 1, pp.63-86, 1999. 
12. Walker, Ernest W., and J. William Petty, II, " Financial Differences between Large and Small Firms," Financial Management, Vol. 7, No. 4, pp.61, 1978.

13. Weld, L.D.H., "The Marketing of Farm Products." Macmillan, New York, NY. Wilkinsson, 1916.

14. I. \& Young, L., "Conceptual and methodological issues in cross cultural relationship research": a commentary on papers by Ahmed et al. and Coviello, Australasian Marketing Journal, Vol. 7, pp. 37-40, 1999.

Table 1: Ratios And Their Calculation

\begin{tabular}{|l|l|}
\hline Variable & Variable Name and Method of Calculation \\
\hline GPM & $\begin{array}{l}\text { Gross profit margin } \\
{[\text { Sales-cost of sales/sales }] \times 100}\end{array}$ \\
\hline NPM & $\begin{array}{l}\text { Net profit margin } \\
{[\text { Income before extraordinary items/sales }] \times 100}\end{array}$ \\
\hline ROE & $\begin{array}{l}\text { Return on Equity } \\
{[\text { Income before extraordinary items/common shareholders' equity }] \times 100}\end{array}$ \\
\hline ROA & $\begin{array}{l}\text { Return on Assets } \\
{[\text { Income before extraordinary items/total assets]x100 }}\end{array}$ \\
\hline ROS & $\begin{array}{l}\text { Return on Sale } \\
{[\text { Income before extraordinary items/annual net sales }] \times 100}\end{array}$ \\
\hline
\end{tabular}

Table 2: T-Test Group Statistics

\begin{tabular}{|c|c|c|c|c|}
\hline GROUP & N & Mean & Std. Deviation & Std. Error Mean \\
\hline GPM internet & 33 & 23.36 & 45.724 & 7.960 \\
Catalog & 23 & 37.20 & 17.725 & 3.696 \\
\hline NPM internet & 33 & -150.17 & 549.472 & 95.651 \\
catalog & 19 & -.28 & 1.022 & .234 \\
\hline ROE internet & 33 & -98.15 & 196.202 & 34.154 \\
catalog & 23 & 62.41 & 288.764 & 60.211 \\
\hline ROA internet & 33 & -54.00 & 86.267 & 15.017 \\
catalog & 23 & 11.04 & 139.042 & 28.992 \\
\hline ROS internet & 32 & -.5138 & .70400 & .12445 \\
catalog & 20 & 1.2970 & 2.82168 & .63095 \\
\hline
\end{tabular}

Table 3 T-Test Statistics For Internet And Catalog Retail

\begin{tabular}{|l|c|c|c|}
\hline Test Statistics & Levene's Test & Sig (2 tailed) & 95\% Interval Contains Zero \\
\hline Gross profit margin & .016 & .122 & yes \\
\hline Net profit margin & .098 & .242 & yes \\
\hline Return on equity & .780 & .016 & no \\
\hline Return on asset & .469 & .035 & no \\
\hline Return on sale & .000 & .011 & no \\
\hline
\end{tabular}

